\title{
60. Isolation of Two Fractions from Chick Embryo Extract which Promote Epidermal Growth
}

\author{
By Sachiko Matsuhashi and Mariko Sezaki \\ Mitsubishi-Kasei Institute of Life Sciences, 11 Minamiooya, Machida-shi, Tokyo \\ (Comm. by Shiro AKabori, M. J. A., April 12, 1975)
}

Interaction between dermis and epidermis during proliferation and development of skin has been reported by several authors. ${ }^{1)-5}$ ) While whole skin grown in culture differentiates quite normally, separated epidermis, when cultured in chemically defined medium without dermis, develops into flattened cells, which cease proliferation and eventually die. Epidermis cultured with nonliving substrate, however, undergoes cell proliferation in the presence of chick embryo extract in the culture medium, as reported by Wessells. $\left.{ }^{6}\right)$ In this paper, it will be reported that two protein fractions which promote proliferation of epidermis can be obtained from chick embryo extract. Their action on epidermis will be discussed.

Methods. Culture of epidermis. Shank skin cut off from 11 day-old chick embryo was incubated for $1.5 \mathrm{hrs}$ at $4{ }^{\circ} \mathrm{C}$ in $\mathrm{Ca}^{++}, \mathrm{Mg}^{++}-$ free Tyrode's solution (CMF) containing $0.025-0.05 \%$ EDTA. Epidermis was then separated from dermis as a sheet after the skin was transferred in CMF. A black millipore membrane filter (MF) with grids of $3 \mathrm{~mm} \times 3 \mathrm{~mm}$ was used as substrate and epidermis was applied to it and then cut into pieces $3 \mathrm{~mm} \times 3 \mathrm{~mm}$ square. They were cultured at $37^{\circ} \mathrm{C}$ in an incubator supplied with $5 \% \mathrm{CO}_{2}$ in air with Waymouth MB 752/1 medium.

Labeling of epidermis with ${ }^{3} \mathrm{H}$-thymidine and counting of the radioactivity. Waymouth medium containing $5 \mu \mathrm{C} / \mathrm{ml}$ of ${ }^{3} \mathrm{H}$-thymidine was used for labeling of epidermal DNA. The labeled tissue was dissolved in $0.1 \mathrm{~N} \mathrm{NaOH}$, precipitated with TCA $(5 \%)$ and the TCA insoluble fraction was collected on a glass fiber filter. Radioactivity on the filter was determined using a scintillation counter.

Results and discussions. Assay system of factor. When epidermis was cultured in a control medium without extract, the rate of ${ }^{3} \mathrm{H}$-thymidine incorporation into the tissue was reduced rapidly to a low level by about $10 \mathrm{hrs}$ of culture and this low level continued at least until $72 \mathrm{hrs}$ of culture. The tissue cultured in a medium with extract, however, maintained a high level of ${ }^{3} \mathrm{H}$-thymidine incorporation although it was reduced once at $10 \mathrm{hrs}$ of culture as shown in Fig. 1. A proportionality between the rate of ${ }^{3} \mathrm{H}$-thymidine incor- 


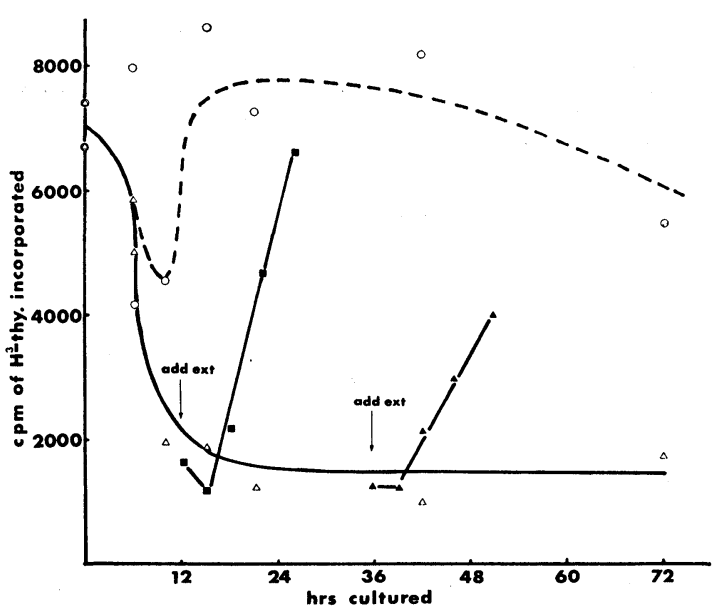

Fig. 1. The rate of ${ }^{3} \mathrm{H}$-thymidine incorporation into DNA during culturing of epidermis. Explants were cultured for the indicated time and then labeled for $4 \mathrm{hrs}$. $\bigcirc-\ldots$ cultured with $20 \%$ extract from beginning of the culture. $\triangle-\triangle$ cultured without extract from beginning of the culture. - cultured for $13 \mathrm{hrs}$ without extract and then with extract added to $20 \%$. A- - cultured for $36 \mathrm{hrs}$ without extract and then with extract added to $20 \%$. The extract used was $30,000 \mathrm{~g}$ supernatant (18 $\mathrm{mg} / \mathrm{ml}$ protein).

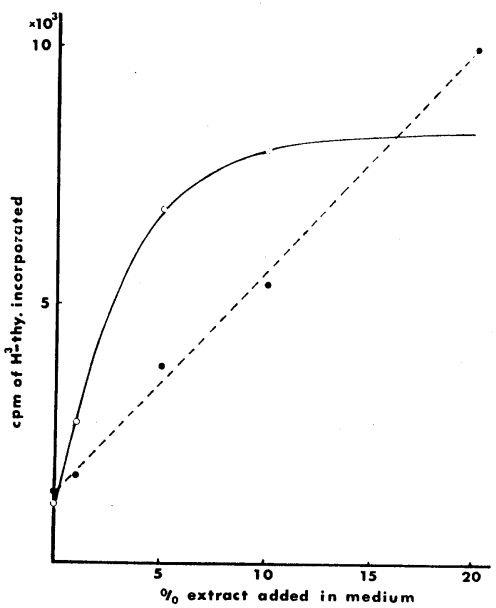

Fig. 2. Effect of different concentrations of extract on ${ }^{3} \mathrm{H}$-thymidine incorporation into DNA. Cultures were pulse labeled for $4 \mathrm{hrs}$ after culturing for $15 \mathrm{hrs}(\bullet-\cdots)$ ) or $42 \mathrm{hrs}(\bigcirc-\bigcirc)$ in medium containing the different amounts of extract as indicated in the figure. The extract used was as same as in Fig. 1. 
poration and the amount of extract added to the medium was found at 15 or $20 \mathrm{hrs}$ of culture. At $24 \mathrm{hrs}$ or $42 \mathrm{hrs}$ of culture, a nonlinear curve was obtained (Fig. 2). The incorporation of ${ }^{3} \mathrm{H}$-thymidine continued lineally for at least $6 \mathrm{hrs}$. From these results, the assay system was designed as follows. Explants of epidermis were cultured for $15-20 \mathrm{hrs}$ in media with and without factor fraction and then pulse-labeled for $2-4 \mathrm{hrs}$ with ${ }^{3} \mathrm{H}$-thymidine. The amount of ${ }^{3} \mathrm{H}$-thymidine incorporated was normalized as radioactivity per $3 \mathrm{~mm} \times 3 \mathrm{~mm}$ square sheet of epidermis and the activity of the factor was expressed by the difference of the radioactivity between the cultures. For assay of the activity of each fraction, 2 different concentrations of the fraction were measured and an average of 3-6 explants was used for each concentration.

More than $90 \%$ of the TCA insoluble radioactivity became soluble in TCA after digestion with DNase.

Purification of the factor. A 2,000 $\mathrm{g}$ supernatant of 11 day-old chick embryo extract was prepared according to Wessells. ${ }^{6)}$ Most of the activity of the $2,000 \mathrm{~g}$ supernatant was recovered in the supernatant after subsequent centrifugation at $45,000 \mathrm{~g}$ for $1 \mathrm{hr}$. As shown in Table I the factor was further purified using the $45,000 \mathrm{~g}$ supernatant as starting material. The procedure of the purification was as follows: To $100 \mathrm{ml}$ of the extract was added $6.5 \mathrm{ml}$ of $20 \%$ of streptomycine sulfate stirring at room temperature and centrifuged for $30 \mathrm{~min}$ at $30,000 \mathrm{~g}$. Half volume of alcohol was added to the supernatant at $-4^{\circ} \mathrm{C}$ and the resultant precipitate was collected by centrifugation as before. The precipitate was extracted with $0.05 \mathrm{M}$ Tris- $\mathrm{HCl} \mathrm{pH} 8.3$ and washed once with the same buffer. The extract and the washing were combined and acidified to $\mathrm{pH} 5$ by $0.1 \mathrm{M}$ acetic acid. The activity was recovered in the precipitate which formed, and which was dissolved in the Tris buffer. This fraction was then further fractionated by ammonium sulfate precipitation (30-70\% saturation). The final faction was then subjected to Sephadex $\mathrm{G}_{100}$ column chromatography, by which two peaks of activ-

Table I. Purification of the factor from chick embryo extract

\begin{tabular}{lccc}
\hline Fractions & $\begin{array}{c}\text { Specific activity } \\
\text { c.p.m. } \\
\text { /mg protein }\end{array}$ & $\begin{array}{c}\text { Total activity } \\
\text { c.p.m. } \\
\text { /total protein }\end{array}$ & $\begin{array}{c}\text { Total protein } \\
\text { mg. }\end{array}$ \\
\hline Crude extract & $5.6 \times 10^{3}$ & $12 \times 10^{6}$ & 2210 \\
Str.-sup. & $11.0 \times 10^{3}$ & $26 \times 10^{6}$ & 2330 \\
Alcohol ppt. & $12.0 \times 10^{3}$ & $7 \times 10^{6}$ & 590 \\
ppt. at pH 5 & $9.4 \times 10^{3}$ & $3 \times 10^{6}$ & 356 \\
Ammonium sulfate ppt. & $21.0 \times 10^{3}$ & $5 \times 10^{6}$ & 226 \\
\hline
\end{tabular}

Protein was determined by Lowry's method.7) 


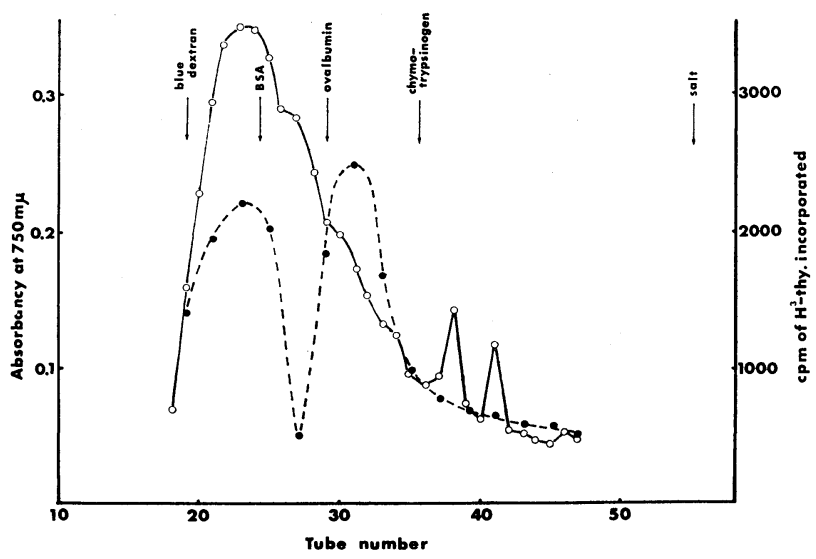

Fig. 3. Sephadex $\mathrm{G}_{100}$ column chromatography. $1 \mathrm{ml}$ of sample $(26 \mathrm{mg} / \mathrm{ml}$ protein) was applied on a column $(1.7 \phi \times 19 \mathrm{~cm})$ equilibrated with CMF and eluted by the same buffer. 15 drops (about $0.75 \mathrm{ml}$ ) was collected in each fraction. The fraction used in this experiment was a fraction treated by DEAE-cellulose at $\mathrm{pH} 8$ (The activity was not absorbed by the resin in this condition) and concentrated by ammonium sulfate precipitation after the ethanol precipitation step (Table I). The sample after the ammonium sulfate precipitation step shown in Table I gave essentially same results. $\bigcirc-\bigcirc$ absorbancy at $750 \mathrm{~m} \mu$ of protein determined by Lowry's method. ${ }^{7)}$ activity of the factor; assay medium contained $5 \%$ of each fraction.

ity were separated as shown in Fig. 3. The molecular weights of the peaks were estimated as 75,000 (peak I) and 38,000 (peak II) daltons from the elution volume, using bovine serum albumin, ovalbumin and chymotrypsinogen as standards (Fig. 3). It is possible that the 2 active peaks represent monomer and dimer of a single factor. Similar results were reported concerning growth factors for several kinds of cells. ${ }^{8)-10 \text { ) }}$

The column fractions of each peak were combined, concentrated by ammonium sulfate precipitation at $\mathrm{pH} 6.7$ and used for the following experiments after dialysis against CMF.

Effects of the fractions on the culture of epidermis. The activity of both fractions peak I and peak II was destroyed by heat treatment for $10 \mathrm{~min}$ at $70^{\circ} \mathrm{C}$, or by trypsin digestion. The relationship between the amount of each fraction added to the culture medium and the incorporation of ${ }^{3} \mathrm{H}$-thymidine into DNA was quite different from that of crude extract, as shown in Fig. 4. In the presence of either fraction, epidermis proliferates, increases its number of cell layers and finally, after culturing for 9 days, produces birefringent substance. 


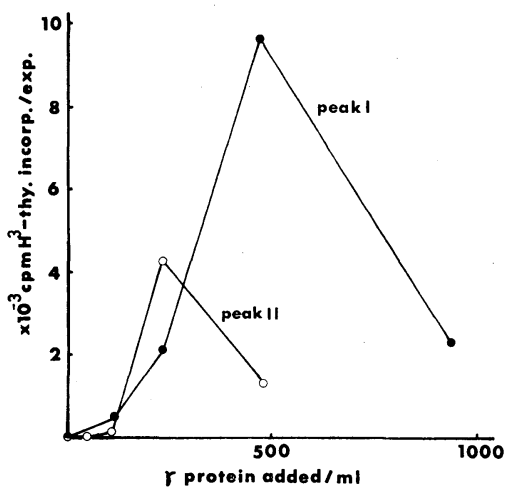

Fig. 4. Effect of different concentration of fractions peak I and peak II on incorporation of ${ }^{3} \mathrm{H}$-thymidine into epidermis.

The explants were cultured for $20 \mathrm{hrs}$ in the medium containing the indicated amounts of fractions and then pulse-labeled for 4 hrs.

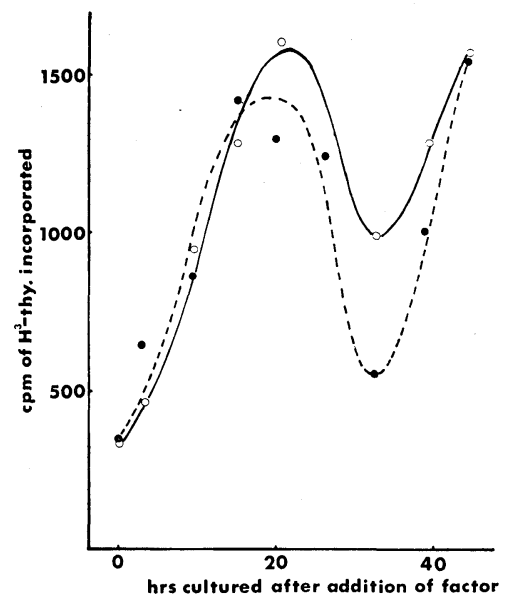

Fig. 5. Restoration of ${ }^{3} \mathrm{H}$-thymidine incorporation of epidermis by the addition of fraction peak I or peak II to the culture medium. Epidermis explants were cultured for $26 \mathrm{hrs}$ without factor and then fraction peak I or peak II was added. The explants were labeled for $2 \mathrm{hrs}$ at the indicated time after addition of the fractions. $\bigcirc-\bigcirc: 555 \mu \mathrm{g} / \mathrm{ml}$ of fraction peak I and - $-288 \mu \mathrm{g} / \mathrm{ml}$ of fraction peak II was added in final concentration.

It is not clear however, if both effects are caused by a single factor because the peak fractions are not pure enough to exclude the presence of a separate factor for keratinization. The hormonal peptide called epidermis growth factor (EGF), ${ }^{11)}$ isolated from submaxillary 
gland of adult male mice, was reported to be effective for proliferation and keratinization of chick embryo epidermis.

When the extract was added to the culture medium after DNA synthesis of epidermis had fallen to low level, DNA synthesis was rapidly restored (Fig. 1). A similar result was obtained when either fraction peak I or peak II was added to epidermis preparation with depressed DNA synthesis (Fig. 5). Furthermore, a second cycle of DNA synthesis was observed when the epidermis was cultured longer in the medium with either of the peak fractions as shown in Fig. 5. From these results, it seems that the cells of epidermis are arrested in the Gl or $\mathrm{S}$ phase of the cell cycle in the absence of the factor, and the factor might induce DNA synthesis within the epidermal cells which then undergo mitosis and a second cycle of DNA synthesis. Investigation of the mechanism of induction of DNA synthesis by the factor and identification of the birefringent substance are now in progress.

Summary. Two fractions which activate DNA synthesis in chick embryo epidermis explants were partially purified from chick embryo extract. The molecular weight of the factors estimated from Sephadex $\mathrm{G}_{100}$ column elution volumes were 75,000 and 38,000 daltons. These factors were inactivated by heat treatment for $10 \mathrm{~min}$ at $70^{\circ} \mathrm{C}$, or by trypsinization. Epidermis cultured in the presence of either of the fractions proliferated and finally produced birefringent substance at 9 days of culture.

Acknowledgement. The authors wish to thank Dr. Y. Kato, Mitsubishi-Kasei Institute of Life Sciences, Tokyo, for his useful discussions.

\section{References}

1) Sengel, P. (1956): C. R. Soc. Biol. Paris, 150, 2057.

2) McLoughlin, C. B. (1961) : J. Embryol. Exp. Morph., 9, 385-409.

3) Wessells, N. K. (1962): Develop. Biol., 4, 87-107.

4) Dodson, J. W. (1967): J. Embryol. Exp. Morph., 17, 83-105.

5) Briggaman, R. A., and Wheeler, C. E. (1968) : J. Invest. Derm., 51, 454-465.

6) Wessells, N. K. (1964) : Pro. Nat. Aca. Sci., 52, 252-259.

7) Lowry, O. H., Rosebrough, N. J., Farr, A. L., and Randall, R. J. (1951) : J. Biol. Chem., 193, 265-275.

8) Ronzio, R. A., and Rutter, W. J. (1973) : Develop. Biol., 30, 307-320.

9) Igarashi, Y., and Yaoi, Y.: Nature, 254, 250 (1975).

10) Honck, J. C., and Cheng, R. F. (1973) : J. Cell. Physiol., 81, 257-270.

11) Cohen, S. (1972) : J. Invest. Derm., 59, 13-16. 